\title{
The Second Language Writing Anxiety: The Perceived Sources and Consequences $^{1}$
}

\author{
İkinci Dilde Yazma Kaygısı: Algılanan Sebepleri ve Sonuçları \\ Elif GENÇ**, Demet YAYLI*** \\ • Geliş Tarihi: $24.07 .2018 \bullet$ Kabul Tarihi: 05.09.2018 • Yayın Tarihi: 01.01.2019
}

\begin{abstract}
Previous studies show that second language writing anxiety negatively influences learners' attitudes, achievement, and performance and hinders their writing and learning process. In line with this, our study focused on capturing the anxiety levels of a group of B2 level EFL learners studying at a preparatory school, and the sources and consequences of their L2 writing anxiety. Both quantitative (SLWAI by Cheng, 2004) and qualitative (a questionnaire with openended questions, and interviews) research methods were used in the study. The results showed that the participants in this study had high to moderate level of L2 writing anxiety. The participants reported that they feel more L2 writing anxiety during exams than writing in class or at home. Topic selection, finding supporting ideas, time limitation, and lack of effective feedback were found to be the most anxiety-provoking factors for the participants, which were followed by grammar for writing, brainstorming, and idea organization.
\end{abstract}

Key Words: Second language writing anxiety, sources of writing anxiety, consequences of writing anxiety

\section{Özet}

İlgili çalışmaların sonuçları yabancı dilde yazma kaygısının öğrencilerin tutumlarını, başarılarını ve performanslarını negatif yönde etkileyerek yazma ve öğrenme süreçlerine ket vurduğunu göstermektedir. Buna paralel olarak, çalışmamız yabancı dil olarak İngilizce öğrenen B2 seviyesindeki bir grup hazırlık okulu öğrencisinin yabancı dilde yazma kaygısı seviyelerini ve bu kaygılarının sebeplerini ve sonuçlarını keşfetmeye odaklanmıştır. Bu çalışmada, hem nicel (İkinci Dilde Yazma Kaygısı Envanteri, Cheng, 2004) hem nitel (açık uçlu soruların olduğu bir ölçek ve mülakatlar) araştırma yöntemleri kullanılmıştır. Sonuçlar, katılımcıların yüksek ve orta düzeyde yazma kaygısına sahip olduklarını göstermektedir. Katılımcılar sınavlarda, sınıfta ve evde yazdıklarından daha fazla kaygı hissettiklerini belirtmişlerdir. Yazma konusu seçme, yardımcı fikir bulma, , zaman kısıtlaması ve etkili dönüt eksikliği en çok kaygı hissettiren etmenler olarak bulunurken bunları dilbilgisi, beyin firtınası, fikirleri organize etme ve konu cümlesi yazma adımları takip etti.

Anahtar Kelimeler: Yabancı dilde yazma kaygısı, yazma kaygısı sebepleri, yazma kaygısının sonuçları

\section{Önerilen Atıf Bilgisi:}

Genç, E.ve Yaylı, D. (2019). The second language writing anxiety: The perceived sources and consequences. Pamukkale Üniversitesi Eğitim Fakültesi Dergisi, 45, 235-251.

\footnotetext{
${ }^{1} \mathrm{Bu}$ çalışma ilk yazarın yüksek lisans tezinden üretilmiştir.

** Yüksek Lisans Öğrencisi, Pamukkale Üniversitesi, Eğitim Bilimleri Enstitüsü, ORCİD: 0000-00030508-7267 e-mail: elif.genc87@gmail.com

*** Prof. Dr., Pamukkale Üniversitesi, Eğitim Fakültesi, Yabancı Diller Eğitimi Bölümü, ORCiD: 00000001-9556-2281, e-mail: demety@pau.edu.tr,
} 


\section{Introduction}

Anxiety, as one of the affective factors, has been a popular research topic for decades. Besides psychologists, second language acquisition researchers and teachers have found it worth studying because of its huge effects on language learning. It is common for learners to have negative feelings such as anxiety, fear, and low motivation in foreign language classes. These feelings can be so serious that learners may skip language classes and even avoid language learning situations. It has been common to study specific skills anxiety for a few decades. A great deal of studies have focused on speaking anxiety (Price, 1991; Phillips, 1992), but recently more research have been carried out on reading, listening, and writing anxiety (Sellers, 2000; Kim, 2000; Cheng, 2004).

Although one has time to think of ideas and form and correct his sentences while writing, it is still quite challenging for many people (Leki, 1999). According to Daly (1978, p.10), writing apprehension is a "situation and subject-specific individual difference concerned with people's general tendencies to approach or avoid situations perceived to demand writing accompanied by some amount of evaluation." Writing anxiety is accepted as "language-skill specific anxiety" (Cheng, et. al., 1999, p.417). The levels of individuals' anxiety can be so high that they tend to choose majors, courses, and even careers without a writing demand (Daly \&Wilson, 1983). Moreover, highly anxious learners have been found to write shorter essays (Faigley, et. al.,1981), have lower self-confidence (Hassan, 2001), get lower scores (Zhang, 2011), and spend less time for planning and organization (Selfe, 1984). To be able to avoid these negative effects of writing anxiety, the sources have also been started to be examined. Some of the most common sources in literature are traumatic past experiences, negative feedback from teachers, lack of writing competence, time limit, fear of negative evaluation, topical knowledge, and linguistic concerns including grammar and vocabulary knowledge.

In this vein, this study aims to scrutinize the levels, sources, and consequences of a group of Turkish EFL students' writing anxiety. Although there have been a few studies on this issue in Turkey (Atay \& Kurt, 2006; Öztürk \& Çeçen, 2007; Susoy \& Tanyer, 2013), studies regarding the university preparatory school students are lacking. The number of studies related to preparatory school students is inadequate and the present study aims to fill this gap by providing aforementioned students' perceptions on sources and consequences, as well as the levels of their writing anxiety. The results may help to improve the elementary and secondary school English language curriculum as well as preparatory school curriculum in higher education. Furthermore, they may take teachers' attention to the significance of creating a stress-free writing atmosphere, identifying anxious learners, and of discovering the underlying causes of learners' failure because there might be more responsibilities for teachers than they think.

The present study aims to answer the following research questions:

1. What are the types and levels of foreign language writing anxiety of a group of B2 level preparatory school students?

2. What are the anxiety levels of these students for different writing environments e.g. home, class, and exam? 
3. What are the students' views on the sources of their foreign language writing anxiety and their suggested ways of dealing with it?

\section{Methodology}

The present study focused on finding out B2 students' foreign language writing anxiety level, its strength and the anxiety sources both qualitatively and quantitatively. With this purpose in mind, we decided to use the embedded design, one of the mixed methods research types. Quantitative method was used to gather numerical information to answer the first research question. As for the second research question, qualitative methods were used to gather details about the students' views and feelings on the sources of their foreign language writing anxiety through semi-structured interviews and a questionnaire with open-ended questions.

\section{Participants}

The participants were all native speakers of Turkish and the B2 students that started the preparatory school in A1 and passed each level successfully. B2 level students were chosen because they wrote full essays in their institution and they are thought to be proficient users of English. The SLWAI was given to all B2 students, 257 of whom were accepted for analysis. The participants of the qualitative parts of the study were two classes with the highest general academic averages (GAA), two with average GAA, and two with the lowest GAA. They were given the questionnaire just after writing the second drafts of their essays throughout five weeks. 89 students took part in the questionnaire with open ended questions, and also 9 students participated in the interviews.

\section{Data Collection Tools}

The study made use of three data collection tools. Firstly, the SLWAI (See Appendix B), developed by Cheng (2004), was conducted in order to collect data about the students' level of anxiety in writing English as a foreign language. It was carried out at the beginning and end of the module to see if there would be a difference in students' anxiety levels between before and after they wrote essays. The SLWAI is a 5-point Likert-scale ranging from 1 (strongly disagree) to 5 (strongly agree). The SLWAI has three sub categories: cognitive, somatic, and avoidance behavior. Cheng (2004) aimed to encompass both English as a second language and also foreign language contexts with his inventory. The adapted version of SLWAI (See Appendix A) used in this study was taken from the study of Ateş (2013). Cheng (2004) found the reliability of the SLWAI 0.91, and a temporal stability of 0.85 test-retest reliability. The estimated reliability (Cronbach's alpha) of the pre-test for the SLWAI in this study was 0.89 .

In order to determine the sources of the FLA of the participants, the participating students both rated their anxiety level with regard to the sources and also explained the reasons of their anxiety after writing the second drafts. This second questionnaire consisted of 16 items in two parts (See Appendix C). The first part aimed to find out if the environment where students write essays could be a source of writing anxiety and was called 'writing environment'. The second part looked into the sources of anxiety in the process of writing; so this part is called 'process'. With these open-ended questions we aimed to encourage the participants to think hard and reflect upon the sources of their possible writing anxiety. The items in this part were specified by carefully examining academic writing course books as well as my experience in teaching writing classes for seven years. After that, it was piloted among 20 students to be sure 
if all the items were clear and if the students had more ideas to add. From the piloting students' answers, a couple of items such as 'punctuation and spelling' were added to the questionnaire. Ten experienced writing teachers, then, analyzed the questionnaire and gave their consent to its content. Lastly, it was piloted in two classes again for a final check of any misunderstandings.

At the end of the module, nine students were interviewed, five females and four males, in order to understand their views and feelings in-depth. Two of the interview questions were taken from Atay and Kurt's study (2006) and some more questions were added specifically related to the study. The participants, in simple terms, were asked to a) name the difficulties they had while writing an essay, b) name the people and situations that cause anxiety, c) explain how anxiety influences their writing performance, d) explain their ways of reducing writing anxiety, and e) suggest ways to reduce writing anxiety in class. These questions helped us capture the participants' views in a detailed way.

\section{Data Collection Procedures}

Data collection had three main stages. First, for the administration of the SLWAI, the students of the 20 classes were given detailed information about the aim of the study. The students used either their names or a nickname so that they would feel more comfortable while providing information. It was given again at the end of the module.

Second, the questionnaire, which questioned the sources of foreign language writing anxiety, was administered to six classes during five weeks after writing their second draft in class. The students were encouraged to write the reasons for their answers as well as rating their anxiety level for each item. Lastly, the researchers carried out interviews with nine students in the last week of the module. The data collection process was completed in two months.

\section{Data Analysis}

The quantitative data - the SLWAI and the Likert scale part of the second questionnaire - were analyzed by using descriptive statistics, one way ANOVA, Scheffe test, and paired groups t-test with the SPSS software for Windows 22.0. As methods of the descriptive statistics, numbers, percentages, means, and standard deviation were used to analyze the data. The findings of both instruments were evaluated at a $95 \%$ confidence interval and $5 \%$ level of significance.

The qualitative data were analyzed through pattern-coding process (Miles \& Huberman, 1994) for the recurrent themes. The steps suggested by Creswell (2014) were followed for coding process and the open-ended questions used in the questionnaire and in the interview formed the main categories for data analysis. The responses were divided into segments which were labeled as codes in the light of the categories at hand. Lastly, the frequencies and percentages were calculated through the numbers of responses with the same codes in each category. To establish the reliability of the analysis of the qualitative data, a colleague also analyzed the data as supported by Creswell and Plano Clark (2007, p.210), and thus, a high level of inter-rater reliability $(85 \%)$ was obtained. 


\section{Findings}

\section{The Types and Levels of the Foreign Language Anxiety}

In order to answer the first research question, the levels of SLWA of B2 level preparatory school students were measured by the questionnaire SLWAI (Cheng, 2004). The mean scores were categorized as stated by Zhang (2011): a mean score above 65 is considered as high level, a mean score lower than 50 as low level, and a mean score between 50 and 65 is considered as moderate level of anxiety. The results of pre-test in Table 1 show that 126 students out of 257 had a high level of second language writing anxiety, 89 students had moderate level, and 42 students had low level of second language writing anxiety.

Table 1: The Results of the SLWAI in the Pre-test and Post-test

\begin{tabular}{|c|c|c|c|c|}
\hline & $\begin{array}{c}\text { Pre-test } \\
\text { Number (n) }\end{array}$ & $\begin{array}{l}\text { Post-test Number } \\
\text { (n) }\end{array}$ & $\begin{array}{c}\text { Pre-test } \\
\text { Percentage }\end{array}$ & $\begin{array}{c}\text { Post-test } \\
\text { Percentage }\end{array}$ \\
\hline Low anxiety & 42 & 35 & 16.3 & 13.6 \\
\hline Moderate anxiety & 89 & 101 & 34.6 & 39.3 \\
\hline High anxiety & 126 & 121 & 49.0 & 47.1 \\
\hline Total & 257 & 257 & 100.0 & 100.0 \\
\hline
\end{tabular}

As seen from the Table 1, 35 students were found to have low level of writing anxiety in the post-test. 101 students had moderate anxiety, while the anxiety of 121 students was high.

As shown in Figure 1, the results showed that somatic anxiety was the most common type of anxiety among students $(\mathrm{M}=2.97)$ in the pre-test. It was followed by avoidance anxiety $(\mathrm{M}=2.92)$, and then cognitive anxiety $(\mathrm{M}=2.85)$. On the other hand, in the post-test, their avoidance anxiety significantly increased, while the other two types of anxieties decreased slightly. The paired samples t-test analysis indicates that there was a statistically significant difference between arithmetic means of the pre-test and post-test of avoidance anxiety $(\mathrm{t}=-$ 2.091; $\mathrm{p}=0.038<0.05)$.

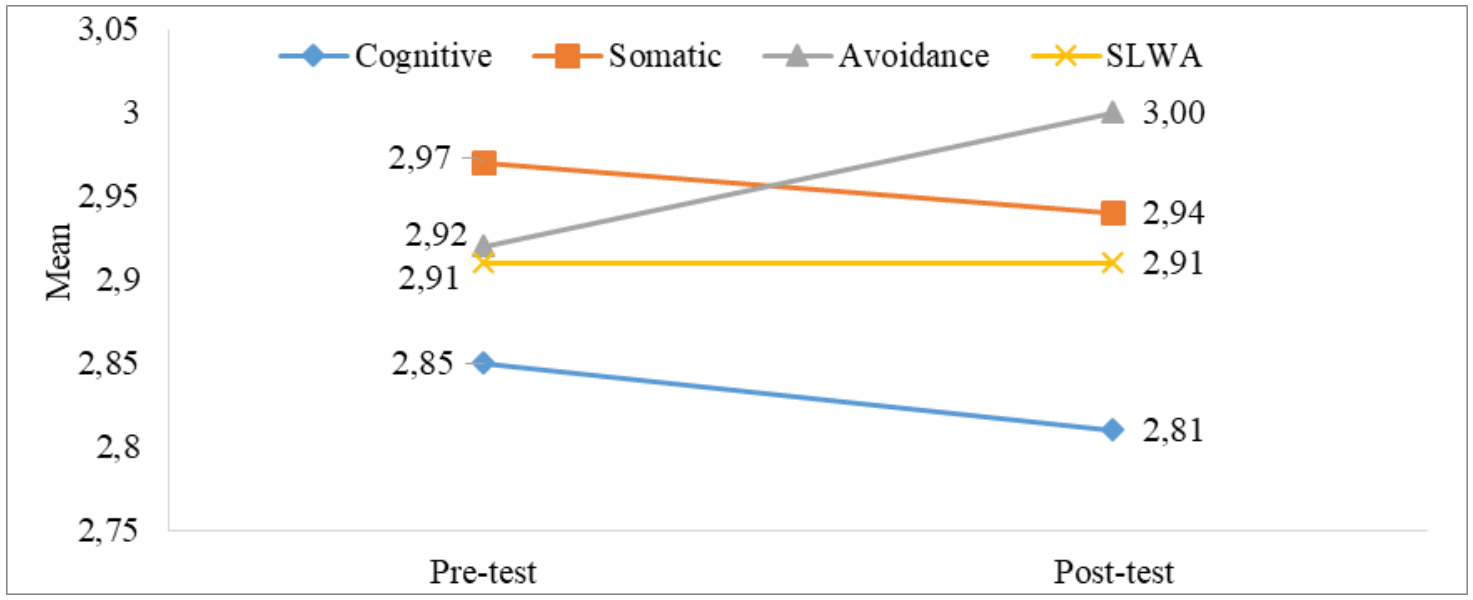

Figure 1.The comparison of means of sub-categories and general second language writing anxiety in the pre-test and post-test

Anxiety levels in different environments and the students' views on the sources of their foreign language writing anxiety 
The second and third research questions asked the most anxiety-provoking environment, the students' views on the sources of foreign language writing anxiety and their suggested ways of dealing with it. In the questionnaire with open-ended questions (See Appendix C), we aimed to collect the participants' views on the sources of their writing anxiety in terms of both context of writing and process of writing. As for the writing environment, we found that the students predictably felt more anxious in the exams, then in class, and finally at home as shown in Figure 2. This may have stemmed from the fact that exams create anxiety-provoking situations. The students explained the reasons for feeling anxious in these different settings as follows: time limitation, classroom atmosphere, concentration in class, the writing topic, fear of low grades and their emotional states.

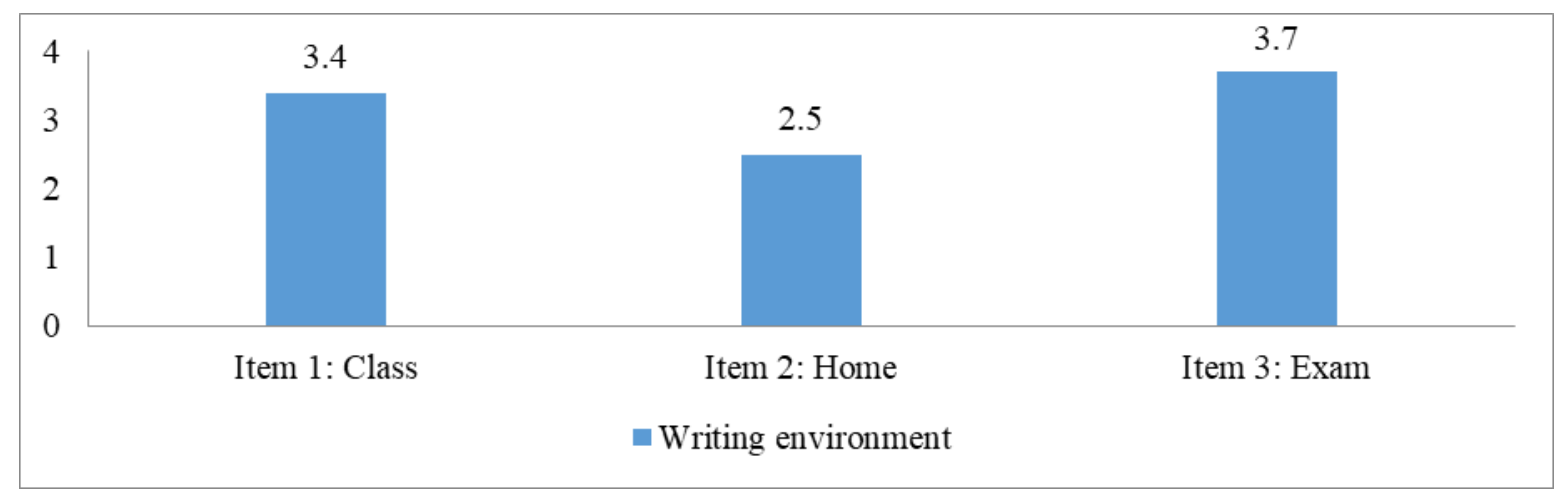

\section{Figure 2. The means of students' anxiety levels with regard to writing environment}

The second part of the same questionnaire looked into the sources of anxiety during writing process. The students ranked their anxiety level for each source and explained the reasons for experiencing this anxiety. The items from 4 to 16 were topic selection (item 4), grammar for writing (item 5), word choice (item 6), punctuation and spelling (item 7), brainstorming (item 8), finding supporting ideas (item 9), organizing ideas (item 10), writing topic sentence (item 11), writing supporting sentences (item 12), writing concluding sentence (item 13), proofreading (item 14), re-writing after receiving teacher's feedback (item 15), and finally re-writing after receiving peer feedback (item 16), respectively.

The item students ranked as the most anxiety provoking source was finding supporting ideas followed by topic selection. Grammar for writing, brainstorming, organizing ideas, and writing topic sentence had the same mean score. On the other hand, the least anxiety provoking sources ranked by the participating students were re-writing after receiving peer feedback, punctuation and spelling, re-writing after receiving teacher's feedback, and proofreading. 


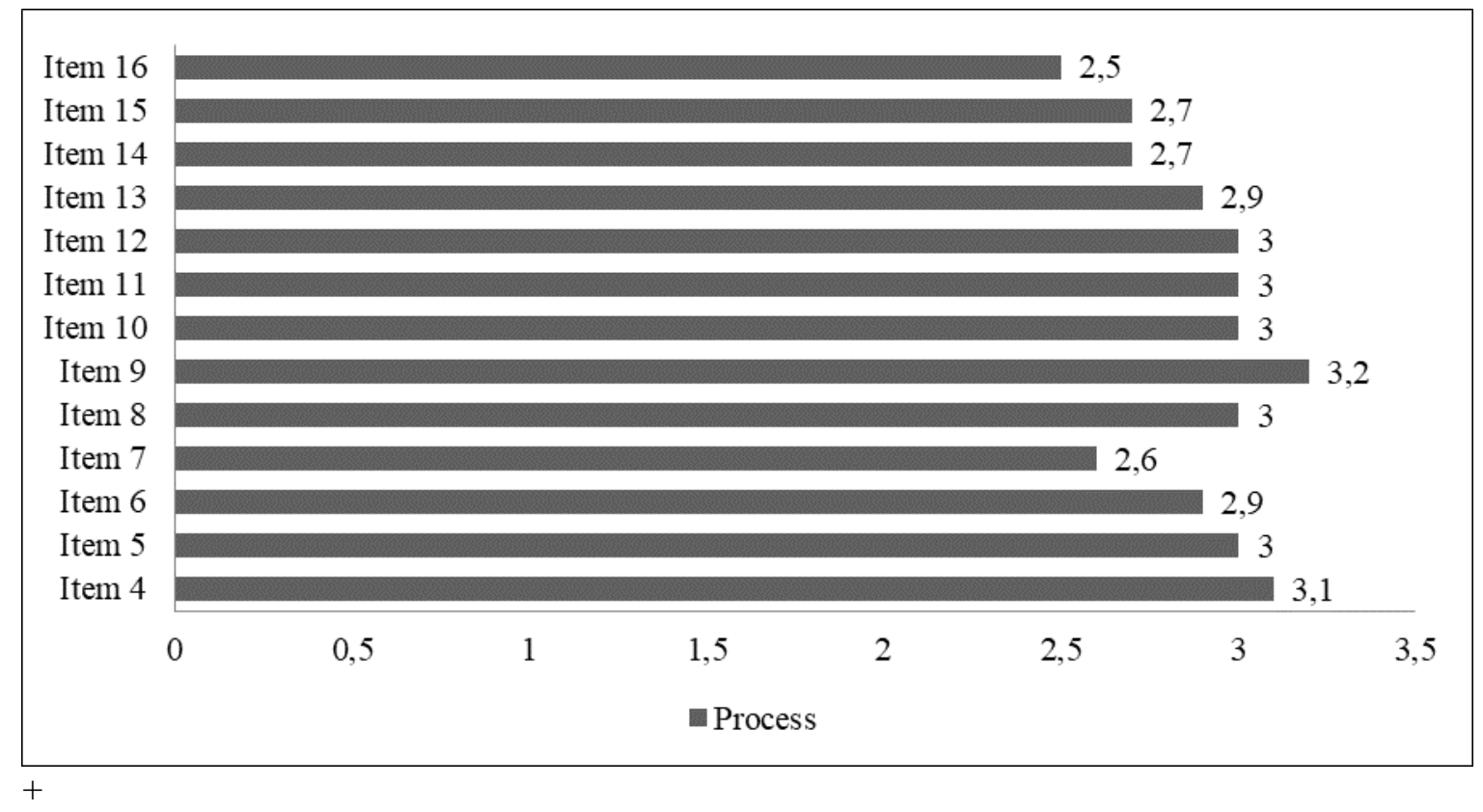

Figure 3. The means of students' anxiety levels with regard to process of writing

The item that the participants felt the most anxious was finding supporting ideas. Lack of topical knowledge (24\%) and being unable to generate ideas (24\%) were the most common reasons under this item. Similarly, several students claimed that learners could not generate ideas because of time limitation and stress. Some other students argued that they could not find ideas when they thought in English. As they stated, having to obey the strict rules of essay writing, such as writing three supporting paragraphs for most of the essay types, had a restricting effect on the students. Thus, one of the ideas would not be of 'high quality'. As one student expressed it, "I feel anxious because I want to find great ideas and support them with examples. My essay must be perfect", a sense of perfection was another reason for being anxious $(6 \%)$.

Topic selection process (item 4) ranked as the second most anxiety provoking item in the present study. In the assignments and exams, the students are given two or three topics to write about. They do not have a chance to select their own topic. $45 \%$ of the participants reported to have difficulty finding three supporting ideas, which was one of the rigid rules of essay writing given in the institution. The next reason was unfamiliarity of topics (22\%). The participants stated that they did not have information about some of the assigned topics, thus they could not generate ideas. The other reasons for feeling anxious in this stage were the participants' worry about writing a good content and deciding on a topic. On the other hand, a number of students $(8 \%)$ uttered that topics were related to the ones they studied in the course book so they did not feel much anxious.

In order to further explore a group of B2 level preparatory school students' sources and consequences of second language writing anxiety and their suggested ways of dealing with it, nine students were interviewed at the end of the module. The most commonly stated difficulties were writing topic itself, time for writing, and unfamiliarity of the genre and type. Only one student reported that he had experienced no difficulty, thanks to his daily studying habit. Two students explained that they used to face some difficulties when they first started to write essays 
in the previous module, yet they overcame them thanks to the teachers and by being more competent in English language over time. As for the people and situations that caused writing anxiety for them, they mostly emphasized time restriction, their poor vocabulary knowledge and poor grammar knowledge as the main sources of their L2 writing anxiety. Due to their perceived incompetency in the language and ineffective feedback from teachers, they had a fear of getting low grades and negative evaluation. These were followed by teachers and the participants' low self-confidence.

As another concern of the present study, the participants were asked to indicate the effects of their writing anxiety on their performance. All the students but one reported that the writing anxiety had negative effects on their performance. Only one student indicated that he felt an urge to study more under stress; thus, anxiety had a facilitating effect on his performance. Four participants reported that they had a great difficulty in constructing essays such as thinking of a thesis statement, finding at least three supporting ideas, or linking the sentences and ideas. Three participants believed that their grades decreased due to their writing anxiety. Some participants brought up the quality and quantity issue of their essays by claiming that they wrote simpler and shorter sentences than they usually did.

The fourth question asked the participants to state whether there were any strategies they used to reduce their writing anxiety. They stated to use strategies mostly in the planning stage of writing. As the most commonly used strategy, they tried to expand their vocabulary knowledge, do research on the topic to be written, and practice.

Lastly, the participants mentioned about their recommendations for teachers who should do their best to help reduce the students' writing anxiety. They mostly reported that giving clear feedback, allocating more time for writing courses and for writing process may reduce their anxiety in class. They also reported that they would appreciate separate vocabulary classes in which vocabulary is taught extensively and in an isolated way so that the use of new vocabulary would not be a problem in student writing. Two participants asked for teachers' more involvement in their composing and rewriting process by helping them with grammar and vocabulary.

\section{Discussion}

The results of the SLWAI show that the majority of the B2 level preparatory school students had high and moderate level of second language writing anxiety. According to MacIntyre and Gardner (1989), language anxiety decreases when the learners' English level gets higher. However, it is seen that the most of the participants in this study experienced high anxiety despite their high level of English. This may be relevant to Cheng's (2002) assertion that it is more important how learners perceive their writing competence rather than their actual competence. Thus, students' having accurate judgments about themselves is as significant as their competence in writing and in the language.

As for the types of second language writing anxiety, in the pre-test, the students experienced somatic anxiety most, similar to the results in studies by Atay and Kurt (2007), Min and Rahmat (2014), and Golda (2015). At the beginning of the module, they experienced more unpleasant physical symptoms such as rapid heart rate, feeling tense, and perspiring. The anxiety type that students experienced least was cognitive anxiety. At the end of the module, 
however; the students tried to avoid situations to write, to excuse themselves when asked to write in English, and preferred not to use English unless they had no choice, which is consistent with the study of Kirmızı and Kirmız1 (2015). As Daly (1978) stated, highly anxious students tend to avoid situations requiring writing. Thus, it is predictable that the students in the present study showed avoidance behavior, as many of them experienced high to average writing anxiety.

The item that the participants felt the most anxiety-provoking was finding supporting ideas. Having difficulty to produce ideas or producing less well-developed ideas has been listed as a feature of highly anxious learners in the literature (Faigley, et. al., 1981; Daly \& Wilson, 1983; Selfe, 1984). Several students claimed that they could not generate ideas because of time limitation and stress. It could be implied that the relationship between anxiety and creativity, such as producing ideas, is bidirectional. The learners fail to create ideas due to their high anxiety and they experience high anxiety when they cannot create ideas.

The assigned topics play an important role for the learners while writing. In order to write effectively, a person needs to have appropriate cognitive schemata and relevant vocabulary knowledge (Hyland, 2003). Thus, while familiar topics may help to create positive attitudes towards the writing task, unfamiliar topics can be disadvantageous for the students. As Cheng (2004) discussed, challenging topics may increase not only less skilled writers' but also highly skilled writers' anxiety. The sources of second language writing anxiety found in the present study are mostly in line with the literature. Also, most of the difficulties and sources of anxiety regarding pre-writing, writing, and post-writing stages were discovered through the qualitative questionnaire and the interview transcripts generally accorded with these findings. For example poor vocabulary and grammar knowledge, writing topic, and classroom environment were found as the reasons that made the students anxious in the questionnaire and same or very similar views were captured also in the interview.

As mentioned several times by the participants, writing under time restriction was the number one source of their writing anxiety. Timed writing was found to prevent students from going through an efficient thinking process which is necessary for writing (Lee, 2003). Many things need to be taken into consideration while writing such as the content, organization, correct and various use of structures and words, mechanics, and etc. They all require enough time for all writers, but especially for student writers. The participants in this study mentioned that time limit affected their word choice, creating ideas and searching about the topic, finishing on time, writing a good essay, and the quality of the sentences they formed negatively. To them these negative effects of time limit all resulted in low grades and failure.

The participants recommended that teachers should give clear feedback, allocate more time for writing and writing classes, and spend more time for teaching vocabulary. According to the results of the study, teachers should realize the impact of writing anxiety in their classes and find ways to reduce it. 


\section{References}

Atay, D., \& Kurt, G. (2006). Prospective teachers and L2 writing anxiety. Asian EFL Journal, 8(4), 100118.

Ateş, S. (2013). Foreign language writing anxiety of prospective EFL teachers: How to reduce their anxiety levels (Unpublished master dissertation). Retrieved from Yüksek Öğretim Kurulu Ulusal Tez Merkezi. (370433).

Cheng, Y., Horwitz, E. K., \& Schallert, D. L. (1999). Language anxiety: Differentiating writing and speaking components. Language Learning, 49, 417- 446.

Cheng, Y. S. (2002). Factors associated with foreign language writing anxiety. Foreign Language Annals, 35(6), 647-656.

Cheng, Y. S. (2004). A measure of second language writing anxiety: Scale development and preliminary validation. Journal of Second Language Writing, 13(4), 313-335.

Creswell, J. W. (2014). Educational research: Planning, conducting, and evaluating quantitative and qualitative research. Upper Saddle River, N.J: Pearson/Merrill Prentice Hall.

Creswell, J. W., \& Plano Clark, V. L. (2007). Designing and conducting mixed methods research. Thousand Oaks, California: SAGE Publications.

Daly, J. A. (1978). Writing apprehension and writing competency. The Journal of Educational Research, 72(1), 10-14.

Daly, J. A., \& Wilson, D. A. (1983). Writing apprehension, self-esteem, and personality. Research in the Teaching of English, 17(4), 327-341.

Faigley, L., Daly, J. A., \& Witte, S. P. (1981). The role of writing apprehension in writing performance and competence. Journal of Educational Research, 75, 16-21.

Golda, T. L. (2015). Exploring reasons for writing anxiety: A survey. The Journal for English Language and Literary Studies, 5 (2), 40-44. Retrieved from http://www.tjells.com/article/587_Golda\%20Albert.pdf

Hassan, B. A. (2001). The relationship of writing apprehension and self-esteem to the writing quality and quantity of EFL university students. Mansoura Faculty of Education Journal, 39, 1-36.

Hyland, K. (2003). Second language writing. New York: Cambridge University Press.

Kırmızı, Ö. \& Kırmızı, G.D. (2015). An investigation of L2 learners' writing self-efficacy, writing anxiety and its causes at higher education in Turkey. International Journal of Higher Education, 4(2), 57-66.

Kim, J-H. (2000). Foreign language listening anxiety: A study of Korean students learning English (Unpublished doctoral dissertation). The University of Texas, Austin.

Lee, S. Y. (2003). Teaching EFL writing in the university: Related issues, insights, and implications. Journal of National Taipei Teachers College, 16 (1), 111-136.

Leki, I. (1999). Techniques for reducing second language writing anxiety. In D. J. Young (Ed.), Affect in foreign language learning: A practical guide to creating a low-anxiety classroom atmosphere (6488). Boston: McGraw Hill.

MacIntyre, P.D., \& Gardner, R.C. (1989). Anxiety and second language learning: Toward a theoretical clarification. Language Learning, 39(2), 251-275.

Miles, M.B., \& Huberman, A.M. (1994). Qualitative data analysis (2nd ed.). USA: Sage Publications.

Min, L. S., \& Rahmat, N. (2014). English Language Writing Anxiety among Final Year Engineering Undergraduates in University Putra Malaysia. Advances in Language and Literary Studies, 5(4), 102-106. 
The Second Language Writing Anxiety: The Perceived Sources and Consequences

Phillips, E.M. (1992). The effects of language anxiety on student oral test performance and attitudes. The Modern Language Journal, 76, 14-26.

Price, M. L. (1991). The subjective experience of foreign language anxiety: Interviews with highly anxious students. In E. K. Horwitz \& D. J. Young (Eds.), Language anxiety: From theory and research to classroom implications (101-108). Englewood Cliffs, NJ: Prentice-Hall.

Selfe, C. L. (1984). The predrafting processes of four high- and four low-apprehensive writers. Research in the Teaching of English, 18(1), 45-64.

Sellers, V. D. (2000), Anxiety and reading comprehension in Spanish as a foreign language. Foreign Language Annals, 33, 512-520.

Zhang, H. (2011). A study on ESL writing anxiety among Chinese English majors: Causes, effects and coping strategies for ESL writing anxiety (Master dissertation). Kristianstad University, Sweden.

\section{APPENDICES}

\section{APPENDIX A: The Second Language Writing Anxiety Inventory (SLWAI) by Cheng (2004): The Adapted Version}

\section{AD SOYAD:}

SINIF:

$\mathrm{Bu}$ ölçek yabancı dilde yazma kaygınızı ölçmek amacıyla hazırlanmıştır. Bu ölçeğin sonuçları araştırma için kullanılacaktır ve eğer bu araştırmaya katılmak istiyorsanız sorulara dikkatli ve samimi cevaplar vermenizi rica ediyoruz. Katılımınız için teşekkür ederiz. HER BİR İFADEYİ OKUDUKTAN SONRA SIZE EN UYGUN OLAN SEÇENEĞİ İŞARETLEYINİZ.

\begin{tabular}{|c|c|c|c|c|c|c|}
\hline & & $\begin{array}{l}\text { 5. Kesinlikle } \\
\text { katıllyorum }\end{array}$ & $\begin{array}{c}4 . \\
\text { Kat1lyyorum }\end{array}$ & $\begin{array}{c}3 . \\
\text { Kararsizım / } \\
\text { Fikrim yok }\end{array}$ & $\begin{array}{l}2 . \\
\text { Katılmiyorum }\end{array}$ & $\begin{array}{l}\text { 1. Kesinlikle } \\
\text { Katılmıyorum }\end{array}$ \\
\hline 1. & $\begin{array}{l}\text { İngilizce yazarken hiç } \\
\text { kaygılanmiyorum. }\end{array}$ & & & & & \\
\hline 2. & $\begin{array}{lr}\text { Kısıtlı } & \text { zamanda } \\
\text { İngilizce } & \text { kompozisyon } \\
\text { yazarken } & \text { kalbimin } \\
\text { çarptığını } & \end{array}$ & & & & & \\
\hline 3. & $\begin{array}{l}\text { Değerlendirileceğini/ } \\
\text { notlandırılacağını } \\
\text { bildiğimde İngilizce } \\
\text { kompozisyon yazarken } \\
\text { kendimi endişeli ve } \\
\text { rahatsız hissediyorum. }\end{array}$ & & & & & \\
\hline 4. & $\begin{array}{l}\text { Düşüncelerimi sı s1k } \\
\text { İngilizce yazmayı } \\
\text { tercih ediyorum. }\end{array}$ & & & & & \\
\hline 5. & $\begin{array}{lr}\text { İngilizce } & \text { kompozisyon } \\
\text { yazmaktan } & \text { genelde } \\
\text { elimden } & \text { geldiğince } \\
\text { kaçınmaya } & \end{array}$ & & & & & \\
\hline
\end{tabular}




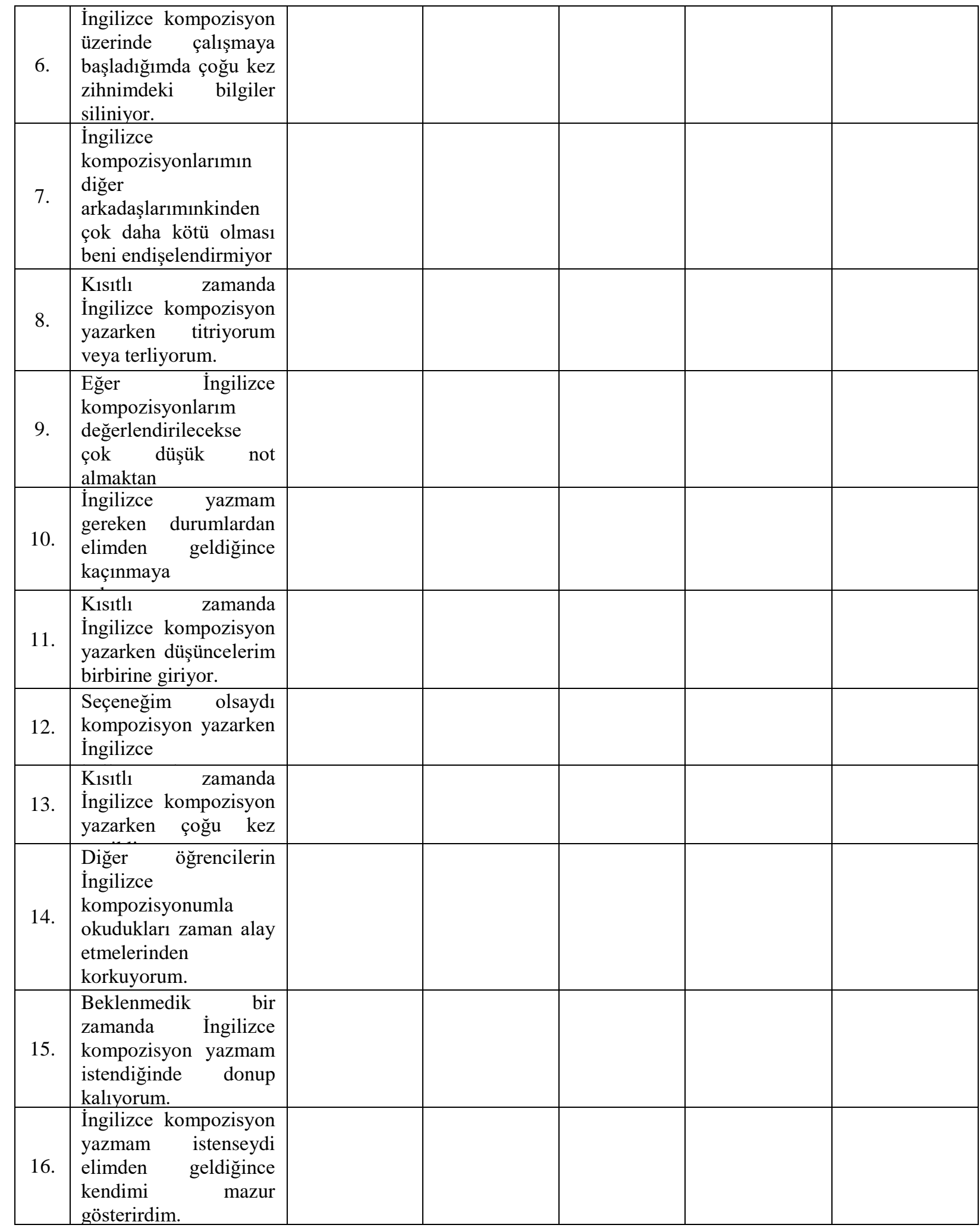


The Second Language Writing Anxiety: The Perceived Sources and Consequences

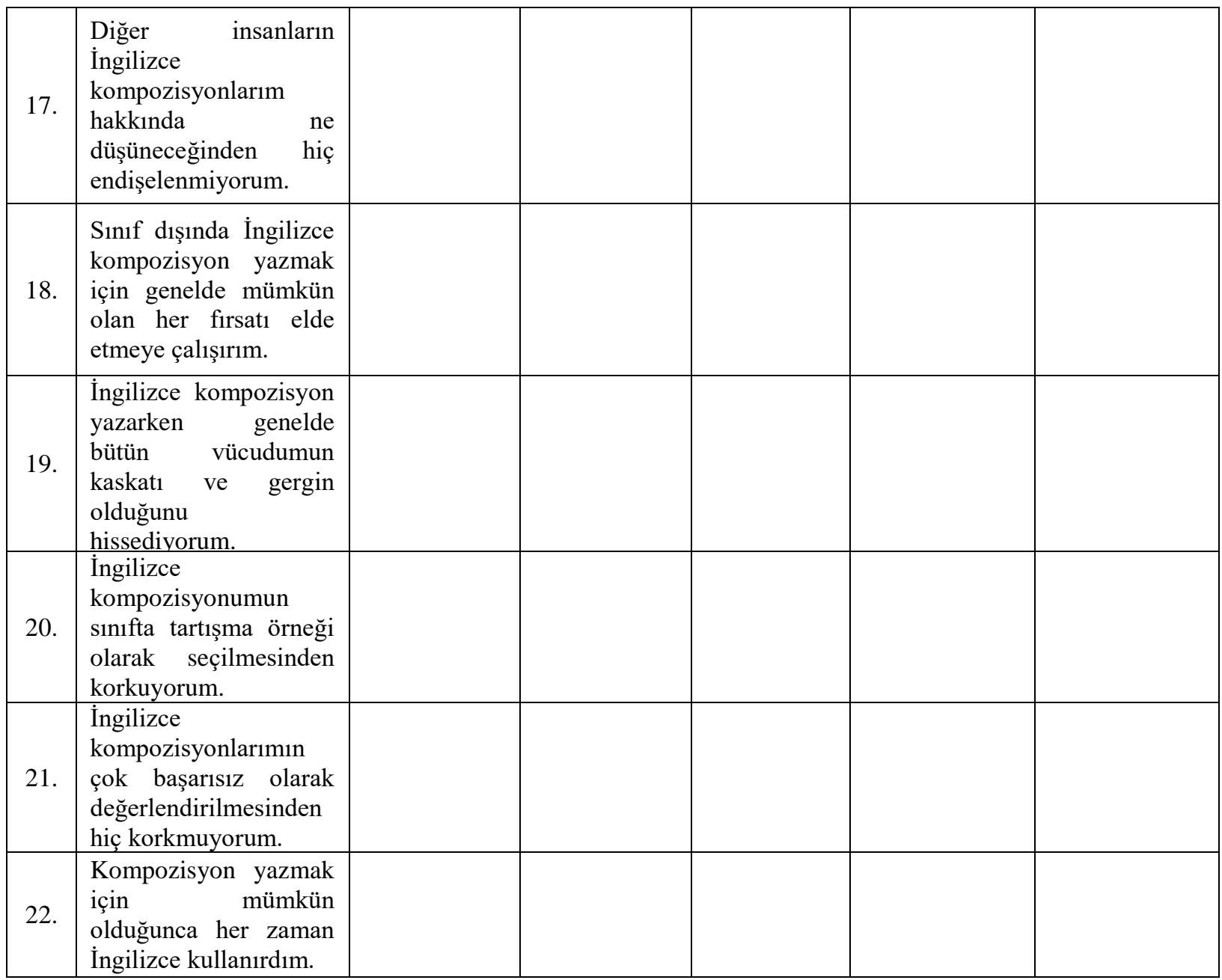

APPENDIX B: The Second Language Writing Anxiety Inventory (SLWAI) by Cheng (2004) Original Version

\begin{tabular}{|c|l|l|l|l|l|l|}
\hline & \multicolumn{1}{|c|}{$\begin{array}{c}\text { 5. Strongly } \\
\text { Agree }\end{array}$} & 4. Agree & $\begin{array}{c}\text { 3. } \\
\text { Undecided }\end{array}$ & 2. Disagree & $\begin{array}{c}\text { 1. Strongly } \\
\text { Disagree }\end{array}$ \\
\hline 2. & $\begin{array}{l}\text { While writing in English, I am } \\
\text { not nervous at all. }\end{array}$ & $\begin{array}{l}\text { I feel my heart pounding when } \\
\text { under time constraint. }\end{array}$ & & & & \\
\hline 3. & $\begin{array}{l}\text { While writing English } \\
\text { compositions, I feel worried } \\
\text { and uneasy if I know they will } \\
\text { be evaluated. }\end{array}$ & & & & & \\
\hline
\end{tabular}




\begin{tabular}{|c|c|c|c|c|c|c|}
\hline 4. & $\begin{array}{l}\text { I often choose to write down } \\
\text { my thoughts in English. }\end{array}$ & & & & & \\
\hline 5. & $\begin{array}{l}\text { I usually do my best to avoid } \\
\text { writing English compositions. }\end{array}$ & & & & & \\
\hline 6. & $\begin{array}{l}\text { My mind often goes blank } \\
\text { when I start to work on an } \\
\text { English composition. }\end{array}$ & & & & & \\
\hline 7. & $\begin{array}{l}\text { I don't worry that my English } \\
\text { compositions are a lot worse } \\
\text { than others. }\end{array}$ & & & & & \\
\hline 8. & $\begin{array}{l}\text { I tremble or perspire when I } \\
\text { write English compositions } \\
\text { under time pressure. }\end{array}$ & & & & & \\
\hline 9. & $\begin{array}{l}\text { If my English composition is } \\
\text { to be evaluated, I would worry } \\
\text { about getting a very poor } \\
\text { grade. }\end{array}$ & & & & & \\
\hline 10. & $\begin{array}{l}\text { I do my best to avoid } \\
\text { situations in which I have to } \\
\text { write in English. }\end{array}$ & & & & & \\
\hline 11. & $\begin{array}{l}\text { My thoughts become jumbled } \\
\text { when I write English } \\
\text { compositions under time } \\
\text { constraint }\end{array}$ & & & & & \\
\hline & & $\begin{array}{l}\text { 5. Strongly } \\
\text { Agree }\end{array}$ & 4. Agree & $\begin{array}{c}3 . \\
\text { Undecided }\end{array}$ & 2. Disagree & $\begin{array}{l}\text { 1. Strongly } \\
\text { Disagree }\end{array}$ \\
\hline 12. & $\begin{array}{l}\text { Unless I have no choice, I } \\
\text { would not use English to write } \\
\text { compositions. }\end{array}$ & & & & & \\
\hline 13. & $\begin{array}{l}\text { I often feel fear when I write } \\
\text { English compositions under } \\
\text { time. }\end{array}$ & & & & & \\
\hline 14. & $\begin{array}{l}\text { I am afraid that the other } \\
\text { students would laugh at my } \\
\text { English composition if they } \\
\text { read it. }\end{array}$ & & & & & \\
\hline 15. & $\begin{array}{l}\text { I freeze up when unexpectedly } \\
\text { asked to write English } \\
\text { compositions. }\end{array}$ & & & & & \\
\hline
\end{tabular}


The Second Language Writing Anxiety: The Perceived Sources and Consequences

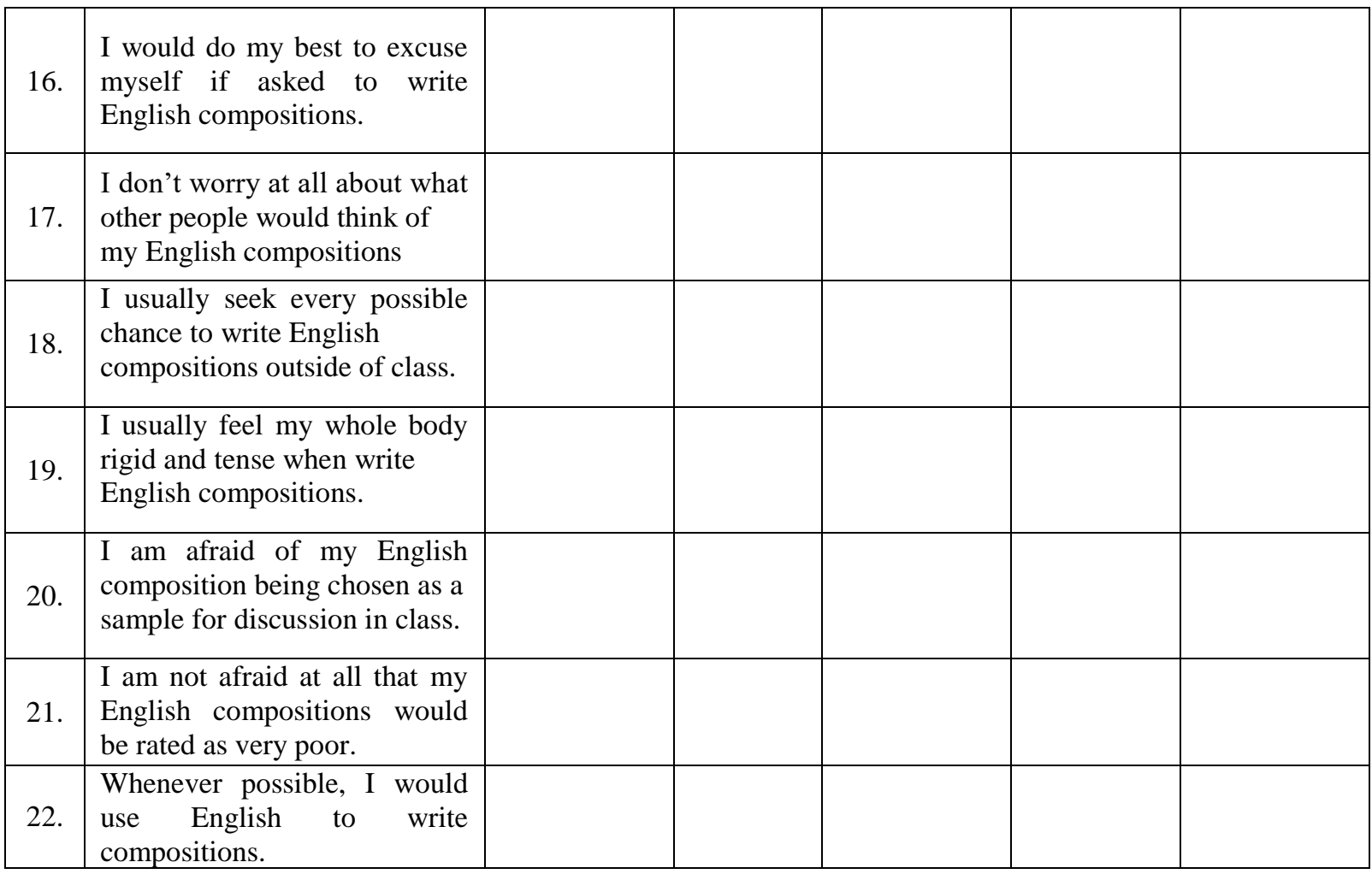

\section{İSIM: $\quad$ SINIF:}

$\mathrm{Bu}$ ölçek yabancı dilde yazma kaygısının sebeplerini araştırmak amacıyla hazırlanmıştır. Eğer araştırmaya katılmak istiyorsanız, lütfen aşağıdaki her madde için kaygı düzeyinizi belirtiniz (1 en az, 5 en çok) ve nedenlerini açıklayınız. Lütfen boş bırakmayınız. Teşekkürler.

\begin{tabular}{|c|c|}
\hline & ...... Essay \\
\hline Context of writing & \\
\hline $\begin{array}{l}\text { Writing in class } \\
1{ }_{-} 2_{-} 3{ }_{-} 4_{-} 5\end{array}$ & Neden? \\
\hline $\begin{array}{l}\text { Writing at home } \\
12_{-} 2_{-}{ }_{-}{ }_{-} 5\end{array}$ & Neden? \\
\hline $\begin{array}{l}\text { Writing in an exam } \\
1{ }_{-} 2_{-} 3{ }_{-} 4_{-} 5\end{array}$ & Neden? \\
\hline Process of writing & \\
\hline $\begin{array}{l}\text { Topic selection (Konu seçimi) } \\
1{ }_{-}{ }_{-} 3{ }_{-}{ }^{-} 5\end{array}$ & Neden? \\
\hline
\end{tabular}




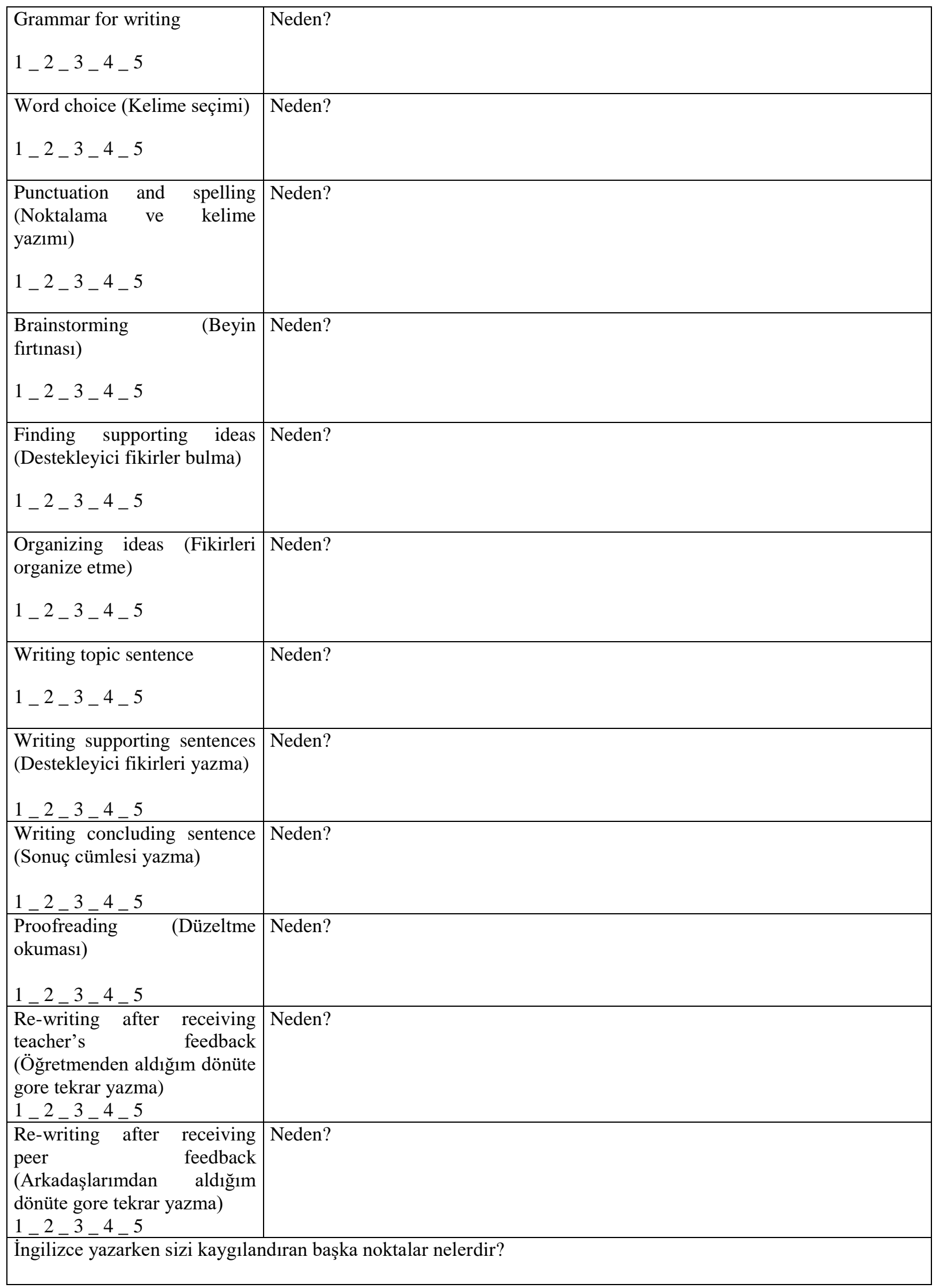




\section{Genişletilmiş Özet}

\section{Özet}

Yabancı dil sınıflarındaki öğrencilerde kaygı, korku ve motivasyon eksikliği gibi olumsuz duygulara benzer bir şekilde oldukça sık görülen bir durumdur. Bu hisler o kadar güçlü olabilir ki bazı öğrenciler derslerden ve hatta yabancı dil öğrenme ortamlarından kaçabilirler. Yazma kaygısı ise ana dilde olduğu gibi yabancı dilde de birçok insan için yaygın bir kaygı türüdür. Yapılan çalışmalar yüksek kaygılı öğrencilerin daha kısa kompozisyonlar yazdıklarını (Faigley ve diğ., 1981), daha az özgüvenli olduklarını (Hassan, 2001), daha düşük notlar aldıklarını (Zhang, 2011) ve plan ve organizasyon için daha az zaman harcadıklarını (Selfe, 1984) göstermiştir. Bu bağlamda, bu çalışmamız bir grup hazırlık okulu öğrencisinin yabancı dilde yazma kaygısının seviyeleri, sebepleri ve sonuçlarını incelemeyi amaçlamıştır. Bu konuyu ülkemizde araştıran çalışmalar olsa da hazırlık okullarını araştıran çalışma sayısı oldukça azdır.

\section{Yöntem}

$\mathrm{Bu}$ çalışmanın katılımcıları bir vakıf üniversitesinde okuyan B2 seviyesi hazırlık okulu öğrencileridir. Öncelikle, 257 öğrenci Cheng'e (2004) ait İkinci Dilde Yazma Kayg1 Envanterini (SLWAI) ilk ve son test olarak tamamladılar. Buna ek olarak, 89 öğrenci, sebeplere yönelik kaygı seviyelerini derecelendirerek ve nedenlerini yazarak açık uçlu sorulardan oluşan ölçeğe katıldılar. Bu ölçek öğrencilere her hafta ikinci taslağı yazdıktan hemen sonra beş hafta boyunca verildi. Aynı zamanda, modülün sonunda 9 öğrenci ile görüşlerini ve duygularını derinlemesine anlamak için mülakat yapıldı. Nicel veriler SPSS programı ile betimleyici istatistik yöntemi kullanılarak; nitel veriler ise içerik analizi yapılarak incelendi.

\section{Bulgular ve Tartışma}

Sonuçlar, katılımcıların yüksek ve orta düzeyde yazma kaygısına sahip olduklarını gösterdi. Bu sonuç dilde yeterliliğin artmasıyla kaygının düştügünü iddia eden MacIntyre ve Gardner'la (1989) uyumlu değildir. Modülün başlangıcında, Atay ve Kurt (2007) ve Golda'nın (2015) sonuçlarıyla uyumlu şekilde en çok fiziksel kaygı hissedildiği gözlemlenirken; modülün sonunda daha çok kaçma davranışı gösterildiği belirlenmiştir ve bu sonuç Kırmızı ve Kırmızı'nın (2015) sonuçlarına benzerdir. Katılımcılar sinavlarda, sınıfta ve evde yazdıklarından daha fazla kaygı hissettiklerini belirtmişlerdir. Yabancı dilde en çok yazma kaygısı oluşturan sebepler ise yardımcı fikirler bulma, konu seçimi, zaman sınırlaması, dil/kelime bilgisi eksikliği ve etkili dönüt eksikliği olarak bulunmuştur. Katılımcılar, kaygılarının genellikle makalelerini oluşturma, notları ve makalelerinin niteliği ve niceliği üstünde negatif etkileri olduğunu ve kaygılarını azaltmak için planlama aşamasında strateji kullandıklarını belirtmişlerdir. Katılımcılar, öğretmenlerin açık ve net dönüt vermelerini, yazmaya, yazma dersine ve kelime öğretimine daha çok zaman ayırmalarını önermişlerdir. $\mathrm{Bu}$ çalışmanın sonuçlarına göre öğretmenler yazma kaygısının etkilerini fark etmeli ve bunu azaltmanın yollarını aramalıdırlar. 